\title{
PELATIHAN PEMANFAATAN INTERNET DIBIDANG $E$ - COMMERCE DALAM MENINGKATKAN JANGKAUAN PEMASARAN PRODUK UMKM DESA PAMULIHAN KECAMATAN SUBANG
}

\author{
Rio Andriyat Krisdiawan dan Yulyanto \\ Fakultas Ilmu Komputer, Universitas Kuningan, Indonesia \\ E-mail : rioandriyat@uniku.ac.id
}

\begin{abstract}
UMKM (Micro, Small and Medium Enterprises) are productive businesses that are needed by individuals and business entities that have fulfilled the criteria as micro businesses. UMKM are distributed in full, each covering micro, small and medium enterprises according to law No. 20 of 2008. When the economic conditions in the village are developed and independent, the community will prosper. Pam Recovery Village has good potential, approved yields, agriculture, and animal husbandry. The economic condition of the pamovery village is supported by market activities and the release away from shipping is less strategic in marketing products. The development of the internet and technology, such as marketing media, known as e-commerce. How can the potential of villages that have been managed in the presence of UMKM be known to the wider community, one of them by utilizing e-commerce media. The focus of community service in the Pam Recovery village in the Kuningan regency that helps and provides assistance in using e-commerce media for UMKM to improve MSME marketing products that are broader, creative and innovative, can improve the livelihoods of the people of the recovery village.
\end{abstract}

Keywords: Micro, Small and Medium Enterprises), e-commerce

\begin{abstract}
Abstrak
UMKM (Usaha Mikro Kecil dan Menengah) adalah usaha produktif yang dimiliki perorangan maupun badan usaha yang telah memenuhi kriteria sebagai usaha mikro. UMKM dibedakan secara masing-masing meliputi usaha mikro, usaha kecil, dan usaha menengah sesuai undang-undang no.20 tahun 2008. Pertumbuhan perekonomian nasional tidak terlepas dari perekonomian pedesaan karena sebagian besar masyarakat Indonesia tinggal dipedesaan. Apabila kondisi ekonomi di desa sudah maju dan mandiri maka masyarakat akan sejahtera. Desa pamulihan mempunyai potensi yang baik, diantaranya hasil perkebunan, pertanian, dan peternakan. Kondisi perekonomian desa pamulihan ditopang oleh aktivitas pasar dan letaknya yang jauh dari perkotaan dinilai kurang strategis dalam melakukan pemasaran produk. Perkembangan internet dan teknologi, seperti media pemasaran secara elekronik yang dikenal dengan e-commerce. Bagaimana potensi desa yang sudah dikelola dengan adanya UMKM bisa dikenal oleh masyarakat luas, salah satunya dengan memanfaatkan media e-commerce. Fokus pengabdian kepada masyarakat di desa pamulihan kecamatan subang kabupaten kuningan yaitu melatih dan melakukan pendampingan penggunaan secara terjadwal dalam memanfaatkan media ecommerce kepada pelaku UMKM guna meningkatkan jangkauan pemasaran produk UMKM yang lebih luas, kreatif dan inovatif, sehingga dapat meningkatkan taraf hidup masyarakat desa pamulihan.
\end{abstract}

Kata Kunci : Usaha Mikro Kecil dan Menengah), e-commerce

\section{PENDAHULUAN}

Perekonomian suatu negara akan maju apabila kondisi ekonomi masyarakat pedesaan sudah mandiri dan maju. Untuk itu perlu adanya upaya untuk mendorong 
masyarakat produktif khususnya generasi muda untuk menjadi enteprener sehingga kesempatan membuka lapangan pekerjaan akan terbuka lebar. Hal ini akan sesuai dengan harapan pemerintah untuk mewujudkan cita-cita negara dalam memajukan kesejahteraan umum yang tercantum dalam Undang-Undang Dasar Republik Indonesia. Dengan meningkatnya perekonomian akan mendorong percepatan dalam pembangunan sehingga akan berdampak pada peningkatan taraf hidup masyarakat. Pertumbuhan perekonomian nasional tidak terlepas dari perekonomian pedesaan karena sebagian besar masyarakat Indonesia tinggal dipedesaan. Apabila kondisi ekonomi di desa sudah maju dan mandiri maka masyarakat akan sejahtera. Akan tetapi, untuk mewujudkan masyarakat sejahtera perlu adanya upaya dan dukungan dari pemerintah, baik pemerintah desa, pemerintah daerah maupun pemerintah pusat.

Pemerintah daerah Kuningan bekerja sama dengan Universitas Kuningan berkomitmen untuk mengatasi permasalahan dalam bidang ekonomi. Dalam kegiatan kerjasama ini Universitas Kuningan dipercaya sebagai fasilitor melalui kegiatan pengabdian kepada masyarakat yang bertujuan untuk memberdayakan pelaku UMKM agar lebih meningkat produksinya dan masyarakat produktif agar terdorong dan termotivasi untuk menjadi enterprener sehingga akan menciptakan lapangan pekerjaan. Adapun dalam memberdayakan masyarakat desa melalui kegiatan pengabdian seperti penyuluhan, pelatihan dan pendampingan. Salah satu bentuk kerja sama antara Pemerintah daerah Kabupaten Kuningan dan Universitas Kuningan adalah memberdayakan masyarakat desa. Adapun desa yang akan menjadi sasaran dalam kegiatan Pengabdian ini adalah desa Pamulihan.

Desa Pamulihan merupakan desa yang terletak di ujung selatan Kuningan yang langsung berbatasan dengan Kabupaten salajambe. Desa pamulihan mempunyai potensi yang baik, diantaranya hasil perkebunan, pertanian, dan peternakan. Desa pamulihan mempunyai potensi yang baik, diantaranya hasil perkebunan, pertanian, dan peternakan. Kondisi perekonomian desa pamulihan ditopang oleh aktivitas pasar dan letaknya yang jauh dari perkotaan dinilai kurang strategis dalam melakukan pemasaran produk. Pelaku UMKM yang ada di desa pamulihan dalam menjalankan bisnisnya masih menggunakan cara yang tradisional. Dan kurangnya respon dari generasi muda untuk berwirausaha dalam mengembangkan potensi desa. Berdasarkan data dari desa, bahwa desa Pamulihan mempunyai potensi dalam bidang makanan yang dapat dikembangkan menjadi produk unggulan desa pamulihan. Namun, untuk mengembangkan produk tersebut pelaku UMKM harus merubah konsep bisnis dari tradisional menjadi modern. Sehingga produk yang dihasilkan akan mempunyai kemasan yang baik dan kualitas yang baik dan dapat bersaing di wilayah Kuningan maupun diluar Kuningan. Berdasarkan permasalahan di atas penulis tertarik untuk melakukan program pengabdian kepada masyarakat. Hal ini sesuai dengan tri darma perguruan tinggi yang harus melaksanakan pengajaran, penelitian dan pengabdian. Selain itu, hal ini sesuai dengan visi Universitas Kuningan, menjadi universitas unggul yang memiliki komitmen tinggi terhadap pemberdayaan masyarakat pada tahun 2023. 


\section{METODE PELAKSANAAN}

Berdasarkan permasalahan yang sudah diidentifikasi dan dirumuskan di atas, maka metode pelaksanaan kegiatan yang digunakan dalam pengabdian ini menggunakan metode Pelatihan, dan Pendampingan.

1. Pelatihan merupakan proses belajar mengajar dengan menggunakan teknik dan metode tertentu secara konsepsional dengan tujuan untuk meningkatkan keterampilan dan kemampuan seseorang atau sekelompok orang (Siagian dalam Lubis, 2008). Adapun teknik yang digunakan dalam metode pelatihan ini yaitu:

a. Teknik presentasi informasi yang meliputi ceramah dan diskusi

b. Metode simulasi yang meliputi studi kasus,

2. Pendampingan dilakukan dengan pendekatan individual dan klasikal. Pendekatan klasikal yang dilakukan yaitu pendampingan penggunaan internet dan media social, pembuatan akun e-commerce, upload produk, dan penentuan harga produk sesuai dengan kurir yang telah ditentukan.

Adapun langkah-langkah kegiatan yang dilakukan adalah pemberdayaan UMKM dan pendampingan dalam pemanfaatan media internet bidang e e-commerce. dalam meningkatkan jangkauan pemasaran produk sebagai berikut:

a. Ceramah mengenai internet dan peluang bisnis di internet.

b. Pelatihan mengenai pembuatan akun e-commerce.

c. Pelatihan tentang penentuan harga pokok berdasarkan kurir yang disediakan.

d. Ceramah tentang manajemen bisnis dan strategi pemasaran sesuai dengan kebutuhan pasar.

e. Evaluasi.

\section{HASIL DAN PEMBAHASAN}

Dalam pengabdian ini penulis melakukan kegiatan dengan target kepada anggota UMKM yang diabntu oleh anggota yang lain dalam melakukan pelatihan dan pendampingan secara langsung. Memberikan pemahaman, pengetahuan dan wawasan mengenai teknologi internet melalui ceramah, Memberikan pengetahuan mengenai bagaimana cara memasarkan produk pengemasan dan produk yang berkualitas serta pelayanan yang baik untuk konsumen, Memberikan pemahaman tentang teknologi internet bidang e-commerce, memotivasi masyarakat produktif desa Pamulihan untuk menjadi entrepreneur, meningkatkan pengetahuan dalam menerapkan strategi pemasaran yang baik dengan teknologi internet, memberikan ide-ide kreatif dan inovatif dalam memanfaatkan potensi desa dengan baik khususya mengenai pengembangan produk olahan dari hasil perkebunan dan pertanian. Melakukan pelatihan dan pendampingan secara langsung kesemua pelaku UMKM dalam menerapkan dan memanfaatkan $e$ commerce dalam meningkatkan jangkauan pemasaran produk. 


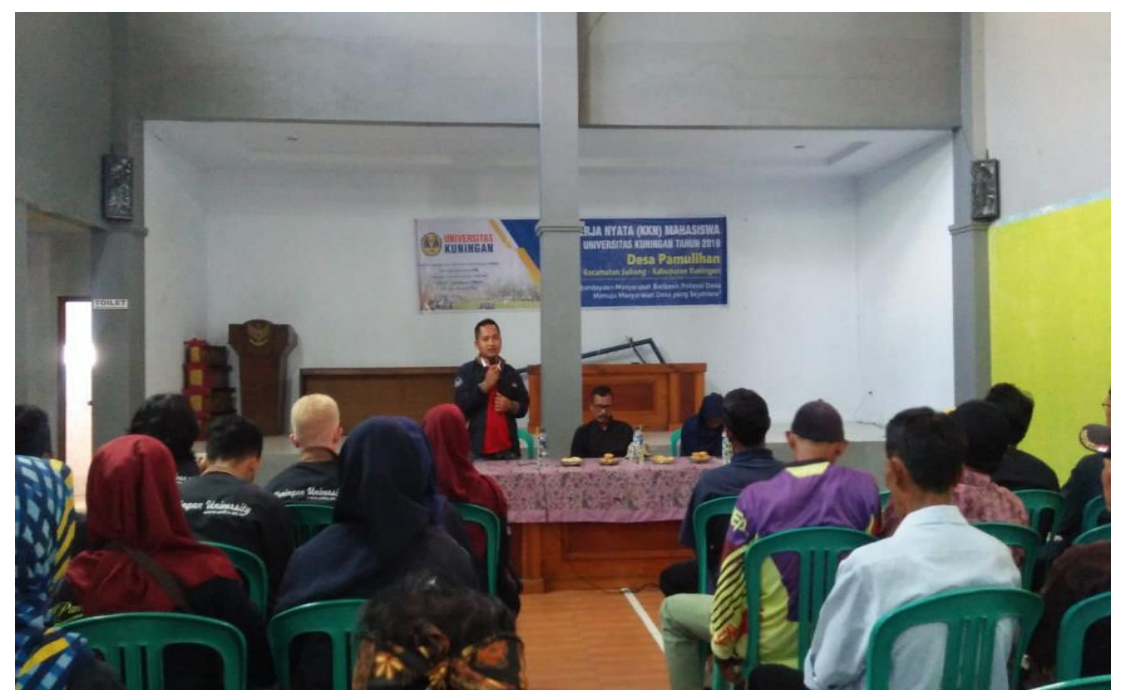

Gambar. Kegiatan Pelatihan Pemanfaatan Internet Dibidang E-Commerce Dalam Meningkatkan Jangkauan Pemasaran Produk UMKM Desa Pamulihan Kecamatan Subang

Berdasarkan solusi yang ditawarkan diharapkan dapat merangsang pelaku UMKM menciptakan ide-ide kreatif dalam mengembangkan produk sehingga dapat berdaya saing dipasar lokal maupun global. Selain itu, untuk mengajak dan memotivasi masyarakat produktif untuk menjadi wirausaha yang baru. Karena wirausaha mempunyai peranan yang sangat penting, yaitu:

a. Sebagai salah satu jalan keluar untuk memecahkan masalah ketenaga kerjaan (mengurangi pengangguran).

b. Turut meningkatkan perekonomian desa agar menjadi mandiri. Hal ini sesuai dengan misi desa pamulihan

c. Meningkatkan pendapatan masyarakat agar sejahtera.

d. Meningkatkan produktivitas faktor-faktor produksi.

e. Mencari peluang dan memanfaatkannya

f. Inovator

\section{SIMPULAN}

Pelatihan dan pendampingan yang dilakukan kepada pelaku UMKM diharapkan dapat meningkatkan pengetahuan dan pemahaman dalam menerapkan pemanfaatan e-commerce dalam meningkatkan jangkauan pemasaran produk, agar UMKM lokal dapat bersaing dipasaran serta dapat menciptakan lapangan kerja bagi masyarakat sekitar. Kegiatan ini dapat melatih pelaku UMKM dalam mengelola bisnis menjadi lebih terencana, terarah dan terkendali, mampu menerapkan strategi pemasaran yang baik denhgan memanfaatkan teknologi internet bidang E-Commerce sehingga produk yang dijual mempunyai kualitas dan dapat melayani konsumen dengan baik. Selain itu, kegiatan ini dapat merangsang dan memotivasi masyarakat produktif untuk berwirausaha karena dengan berwirausaha maka pertumbuhan ekonomi desa akan meningkat dan masyarakat akan sejahtera. Dengan berwirausaha akan menciptakan 
pekerjaan sehingga dapat menyerap tenaga kerja masyarakat sekitar dapat memberikan penghasilan bagi masyarakat yang ikut terlibat dalam UMKM.

\section{SARAN}

Diharapkan pelatihan seperti ini tetap dilaksanakan secara rutin. Dikarenakan perkembangan teknologi yang terus berkembang dan sebagai evaluasi capaian dari tahunketahun. Perlu diadakan kembali pelatihan pemanfaatan teknologi yang lebih luas, bukan hanya untuk meningkatkan jangkauan pemasaran, tetapi untuk pengelolaan dan distribusi yang efektif dan efisien.

\section{UCAPAN TERIMA KASIH}

Penulis ucapkan terima kasih kepada Kepala Desa dan UMKM Desa Pamulihan, Mahasiswa UNIKU, Dekan FKOM UNIKU, Rektor Universitas Kuningan, Pemerintah Daerah Kabupaten Kuningan atas segala dukungan yang telah diberikan sehingga terselenggaranya kegiatan pengabdian ini.

\section{DAFTAR PUSTAKA}

Akhir Lubis, Khairul, Pengaruh Pelatihan dan Motivasi kerja terhadap kinerja karyawan PT.Perkebunan Nusantara IV (PERSEROAN) Medan", (Tesis, Universitas Sumatera Utara Medan) Medan: Unsu Press, 2008.

BPS Kabupaten Kuningan. 2017. Data PDRB Kabupaten Kuningan.

Kasmir. Kewirausahaan. PT. Raja Grafindo Perkasa. Jakarta

LPPM. 2018. Panduan Pengabdian Kepada Masyarakat. Universitas Kuningan

Sukirno, Sadono. 2006. Ekonomi Pembangunan Edisi Kedua. Kencana. Jakarta

Suwari Akhmaddhian dan Erga Yuhandra. 2018. Bantuan Hukum Bagi Tenaga Pendidik

Dan Kependidikan Di Desa Mancagar Kabupaten Kuningan, Indonesia. Empowerment : Jurnal Pengabdian Masyarakat, e-ISSN 2598-2052 Vol. 01 Nomor 01. 2018.72-78.

2019.https://www.ayobandung.com/read/2019/02/13/44992/pertanian-juara-sektorpendukung-perekonomian-kabupaten-kuningan. (Diakses Oktober 2019)

2017.http://www.faktadaerah.com/2017/10/fakta-desa-pamulihan-kuninganprovinsi.html. (Diakses Oktober 2019)

Undang-Undang No.20 tahun 2008 tentang Usaha Mikro Kecil dan Menengah 